\title{
Non-Traditional Skills and Tactics and Modern Technology
}

\author{
Olubunmi Philip Aborisade, College of New Rochelle, New York
}

\begin{abstract}
Technology has introduced many non-traditional skills and tactics into the media and communication landscape. It is no longer business as usual. Every business organization and individuals now find ways and means of doing things differently. This article analyzes the use of non-traditional skills and tactics by organizations and individuals with emphasis on how technology aids the circulation of news about protests, keeps protesters alive and connected, and spreads protests around the world.
\end{abstract}




\section{Background}

The rush for non-traditional methods is evident in today's business environment. Different organizations utilize different skills and tactics in their day-to- day activities. More than ever, the business environment is inundated with non-traditional skills and tactics to enhance performance and maintain high standards. Non-traditional skills and tactics have therefore become imperative for organizations to depart from moribund conventional methods that prove ineffective.

In today's business environment, perhaps the latest in the list of non-traditional methods of doing business is the introduction of virtual team. Duarte and Snyder (2006) see virtual team as a strategy, tool, and technique that succeed. In a virtual organization, communication is done "through e-mail, instant messaging, videoconferencing, databases, and other electronic collaboration tools" (Glen, 2003, p. 48). With these tools, people can work together in the same organization on the same project without ever meeting face-to-face (Glen, 2003).

Virtual team allows organizations to "draw talents from different geographical locations and organizations around the world" (Duarte and Snyder, 2006, p. 3). It is important to note however, that leading a virtual team is not the same as leading a traditional team that is physically present within the same organization. Virtual team requires special skills such as understanding human dynamics and performance, knowledge of how to manage across functional areas and national cultures, career management skills virtually, and ability to use leverage and electronic communication technology for communication and collaboration in the virtual team environment (Duarte and Snyder, 2006, p. 4).

Additionally, leading virtual teams requires "ability to coach distance team members; ability to build trust among dispersed team members; networking with others outside the team such as customers or other stake holders; and remote project management skills" (Nemiro, 2004, p. 26). However, leadership success in virtual team organizations requires that the leadership has tolerance for horizontal moves in the organization, organizational ambiguity, and leadership ability to play both the role of member and leader (Wilson, George, and Wellins, 1994 cited in Nemiro, 2004). 
In news media organizations (the focus of this paper), the use of non-traditional skills and tactics in news gathering, reporting and distribution is on the increase. In particular, mainstream news organizations around the world embrace non-traditional methods and tactics to deliver news to their audiences. The business of journalism is as a result being transformed by new technologies with non-journalists taking advantage of technology to contribute news items to mainstream media. This development led to the emergence of a new form of journalism (non-traditional) which has attracted numerous definitions and nomenclatures. While some call it 'participatory journalism', some call it 'citizenjournalism', others call it 'we media' or 'grassroots journalism'.

\section{Advocates of Non-traditional Skills and Tactics}

Glen (2003) declares in an unequivocal terms, the need to move away from the conventional methods of management when leading those he calls 'geeks' or 'knowledge' workers (Information Technology Professionals). Glen's (2003) argument is that, the peculiar nature of geeks' work does not allow them to operate effectively under the same management style like other workers in the same organization. The author therefore suggests that managers who oversee geeks must not force them to adapt to any style of management with which the manager is comfortable. "As a manager and a leader, you must develop sensitivity to the geek's personality and production style and help each one discover his own best way to produce" Glen (2003, p. 79) charges managers who oversees the geeks.

Like Glen (2004), Senge (1990) illuminates the significance of non-traditional methods in his vision of learning organizations which he see as a non-traditional way by which organizations can achieve the result they desire. The author argues in favor of the concept of Learning Organization as a way to improve performance in organizations rather than leaving knowledge to disappear in organizations for lack of knowledge sharing among employees in an organization. He urges organizations to sustain the momentum in Learning Organization so that their organizations can effectively utilize the concept of Learning Organization to enhance performance. Widen-Wulff (2007) sees Knowledge Management (KM) as a nontraditional method of preserving organizational resources for business success.

Widen-Wulff (2007) is particular about how to preserve information resources for reuse in an organization. The author's concern is that, "many professionals, managers, and policy makers 
have trouble gaining a reliable understanding of the actual roles of information management, technologies and knowledge sharing as causes, catalysts, facilitators and obstacles in workplace" (p. 63). If managers understand these mechanisms, it is believed that, managerial understanding of the roles of knowledge management and knowledge sharing will be enhanced (Huysman and de Wit, 2002).

\section{Technology and Non-traditional Skills and Tactics}

Technology plays a very formidable role in the use of non-traditional skills and tactics in today's business organizations. Contemporary literature is very explicit about the impacts of technology as a veritable weapon to pave way for modern (non-traditional) ways of doing business. Many organizations want to embrace new skills and tactics to carrying out their day-to-day operations rather than being stuck with the traditional methods that is proving inefficient. In view of the need to move away from traditional methods of information management, Ward and Ward and Peppered (2006) emphasize effective utilization of technology so that organizations can maximize to its fullest, the competitive advantage inherent in non-traditional methods. Given the importance of non-traditional skills and tactics in today's business environment, many organizations come up with a list of technologically driven best practices geared toward organizational success, goals, and objectives with the aim of moving away from traditional methods.

\section{A Vote for Non-traditional Media}

The use of non-traditional skills and tactics in journalism by media organizations became popularized in 2005, during Hurricane Katrina when local citizens with no formal ties to media organizations deliver news stories, post photographs and share videos depicting Katrina's devastation (Marshall, 2005). The Tsunami episode in South Asia highlights yet another form of non-traditional journalism by mainstream media organizations. When the Tsunami River wreaked havoc on local citizens, tourists and residents of the area affected by the havoc with digital cameras and phones quickly transmitted images of the disaster to mainstream media, and shared their stories through the World Wide Web. Mainstream media depend on news items sent to them by citizen journalists for the coverage of the bomb blast that rocked the city of London in July 2007. Citizen journalists and blogger present at the scene of the bomb blast used cell phones to send stories to send stories, images, and videos to mainstream media. 
The 2009 presidential election in the United States of America witnessed yet another display of non-traditional tactics and skill in news gathering, reporting, and distribution. During electioneering campaign, local citizens were able to contribute campaign news to mainstream media. The CNN 'Magic Map' was effectively used to collate and analyze electoral results from different location which is unusual in the history of political journalism. Coverage of the election saw bloggers, citizen-journalists, and trained journalists competing for news gathering, reporting and distribution. The use of "Hologram' was perhaps the climax of nontraditional skill displayed by the CNN. With the hologram technology, CNN replicates interviewee from remote locations into the $\mathrm{CNN}$ newsroom for an interview as if the interviewees were physically present in the newsroom.

At the inauguration of the $44^{\text {th }}$ president of the United States of America on January 20, 2009, mainstream media organizations demonstrated the efficacy of no-traditional skills and tactics in journalism. Media organizations asked citizens present at the 'inaugural mall' to send pictures, images and stories of the inauguration from their vantage positions. The CNN 'iReport' and 'YOUTUBE' are remarkable technology driven non-traditional tools that CNN uses effectively in recent times to enhance the gathering and distribution of news. With these tools, citizens around the world with digital camera or phone contribute news stories, videos and images directly to the $\mathrm{CNN}$ website.

The use of web-based software like Twitter, Facebook, and MySpace by news organizations and citizens around the world equally helps the democratization of news gathering, reporting and distribution around the world. These tools provide mainstream media and their audiences the opportunity to collaborate in news gathering, reporting, and distribution. These tools were effectively used in 2011 by ordinary citizens across the world to voice their opinion against their government.

When a 26 year old Tunisian fruit vendor out of frustration set him on fire in a public square it led to protests against dictators in Tunisia, Egypt and Libya. This incidence also rattled regimes in Syria, Yemen and Bahrain and spurred Mexicans against the terror of drug cartels, Greeks to march against unaccountable leaders, Americans to occupy public spaces to protest 
income inequality, and Russia against a corrupt autocracy (Rick, 2011). Earlier in United Kingdom, unemployed youths took to the streets in London and vandalized public places.

From January 1, 2012, Nigerians began to treat the whole world to a display of media tools and tactics as they flooded the information superhighways with stories of protests around the country against government withdrawal of fuel subsidy. Then ordinary citizens took to the streets armed with their internet-ready camera phones to protest the government withdrawal of subsidy and report the protest to the local and international media.

This development confirms the findings in an earlier research (Aborisade, 2010) on citizenjournalism in Nigeria, that new media technology has liberated Nigerians and their media from oppressive regimes. This is unlike the past when media outlets were closed down illegally by government for publishing reports of protest and ordinary citizens had no tools (particularly internet-ready camera phones) to reach the local and international media to tell their stories as they do with new media technology (Aborisade, 2010).

The "Occupy Nigeria activists" re-enacted the mass demonstrations that took place in Egypt's Tahrir Square during the 2011 Arab Spring movement. Protesters in Kano, Nigeria, "Referring to the Silver Jubilee roundabout as "Tahrir Square Kano", the social media networks were abuzz with users posting updates and photos from Kano and calling for food and water donations to be sent to the protesters" (Sahara Reporter, January 4, 2012).

This is not a technological revolution, but the role of technology cannot be underestimated. "Social networks did not cause these movements, but they kept them alive and connected. Technology allowed us to watch, and it spread the virus of protest, but this was not a wired revolution; it was a human one, of hearts and minds, the oldest technology of all" (Rick 2011, December 26 2011-Jannuary 2, 2012).

While one can only marvel at the efficacy and efficiency of technology in facilitating news gathering, reporting and distribution around the world, it is significant to note that the quality of media products can be compromised if news gathering, reporting and distribution are left to non-media persons with no journalism training to handle. The beauty of it all is that, these media and communication technologies make the business of news reporting, gathering, and 
distribution easy and faster unlike in traditional media where most news worthy events are not covered because traditional reporters could not reach the scene of the event. The prevalence of 'citizen-journalists' and 'bloggers' in today's media landscape make it possible for mainstream media to cover events in remote locations through news bloggers and citizenjournalists.

\section{Non-traditional Media Skills and Tactics}

The use of non-traditional skills and tactics by media organizations became an object of rigorous academic discuss. While some are of the view that, non-traditional skills and tactics like citizen-reporting enhance media work, some believe they diminish the standard of media practice around the world. Gillmor (2004) a leading advocate of 'citizen-journalism' describes non- traditional skills and tactics such as 'citizen-journalism' as a way of encouraging participations of media audiences, blogs, mailing list and wikis in media work. Gillmor's (2004) argument in support of 'citizen-journalism' is that, readers and viewers are no longer passive news consumers. They can now use blogging, podcast software, digital camera, phone, and video recorder to contribute news items to mainstream media.

Jost and Hipolit (2006) see 'citizen-journalism' as a way to change politics, business and popular media culture for better. The authors argue that the presence of 'citizen-journalists' will reduce the influence of elite and institutions on mainstream media. They believe involvement of news audience in news gathering, reporting and distribution allows wider public participation and greater interactivity in society. However, the authors' argument in relation to public participation in news gathering, reporting and distribution is an affront on the media which is the mouthpiece of society. Many argue that media obligation to society can only be discharged effectively and efficiently by trained journalists. Despite continued criticisms against 'citizen-journalists', Bowman and Willis (2003) believe they provide a wide range of relevant, independent, reliable, and accurate information that democracy requires. Putting criticisms aside, Lin (2004) argues that, 'citizen-journalists' contribute knowledge to media ecology. Lin (2004) believes the whole idea of 'participatory journalism' is to engage news audience in the process of rationalizing web content and news reporting, gathering, and distributions rather than a deliberate attempt to erode the traditional roles of journalists. 
As media organizations continue to utilize the services of citizen-journalists around the world, media critics continue to protest against what they see as an erosion of the traditional roles of journalists. Pisani (2005) asks whether technology is poised "to subsume the traditional roles of journalists" (p. 48) with the ever- increasing number of computer programs used for news gathering, reporting and distribution. Pisani (2005) further added that, the use of some software to determine the position of news stories on some web sites without human intervention is another way of substituting journalists with the machine. This is seen as an erosion of the traditional roles of journalists. Pisani (2005) believes local citizens who contribute texts, images and videos to news media using technologies such as digital phones and cameras equally erodes the traditional roles of journalists.

In line with Pisani's (2005), local citizens without journalism training who take advantage of technology to contribute news items to mainstream media is not the best. While many see the activities of 'citizen-journalists' or 'news bloggers' as a usurpation of the traditional roles of journalist, there is no doubt that the quality of news items they contribute to news media is sub standard. This is evident in the quality of images, videos, and texts that 'citizenjournalists' and 'news bloggers' offer the public or contribute to mainstream media.

Also, news items by non-journalists lack professional touch because 'citizen-journalists' and 'news bloggers' providing these news items lack requisite professional training for the job they do. There are also ethical concerns regarding the use of 'citizen-reporters' for media work. Since they are not professionals in the job they do, it is obvious they will not know the rules of the game and they are bound to run afoul of ethics of the profession.

The bottom line is that, non-trained journalists cannot do good journalism; it is like someone without law training going into law practice. The result is obvious. One lesson from the ubiquitous nature of citizen-journalists is that, it no longer matters if journalists are excluded from coverage of any event. As long as people are present at the scene of an event, the event will be reported one way or the other either peer-to-peer, on the blog or in the mainstream media. That is the direction the news trend in media is heading.

Long before 'citizen-journalism' became the norm, Koch (1998) envisaged the current debate around 'citizen-journalism'. With the internet, the author warned that, 'journalism is under 
fire' that will force news media to contend with technologically induced revolutionary changes and heightened competition from new sources of news. With the increasing numbers of 'citizen-journalists', 'news bloggers', internet news media, mailing lists, and online discussion groups, the authors' message is clear to all media watchers. While Koch (1998) believes the internet will continue to cause serious undercut in traditional journalistic values, it also concurs that internet has moved journalism from news print to cyberspace with previously unheard voices now partaking in public debate hitherto dominated by elite.

\section{Traditional and Non-traditional Media}

Before the internet, there were three major traditional media outlets-print, radio, and television. The coming of the internet led to the migration of media contents from the three major traditional media to the cyberspace. With the internet, interactivity was heightened as "anyone with a modem computer can start or moderate a conversation" (Gillmor, 2004, p. 45).

This development in the media landscape began a process of media revolution which subsequently led many citizens to want to be part of the process of news gathering, reporting and distribution since the news media outlet of the internet does not impose any stringent measures on anyone that wants to report the news unlike in the traditional media of print, radio and television that is almost closed to non-media practitioners. That was the beginning of what is today known as "citizen-journalism" which is in serious competition with nonmedia practitioners. This equally symbolizes the beginning of internet revolution of the computer and communication world like anything before it (Barry et al., 2005).

There are also other non-traditional methods like news blogs, mailing list, online discussion groups and the use of social media like facebook, twitter etc that have in recent times challenged the traditional methods of news gathering, reporting and distribution. With the competition between the traditional and non-traditional media (old and new media if you like), the audience of the traditional media is polarized as many members of the audience embrace new media and merely use information they gather from traditional media to supplement what they gather from the new media (Boogers and Voerman, 2002). While members of the audience of old media continue to migrate to the new media, journalists in the old media continue to embrace the new media (Gillmor, 2004). The argument therefore is 
whether the new media has come to replace the old media or it is just a passing phase. Contemporary studies have shown that "participatory journalism" or other forms of nontraditional media skills and tactics of news gathering, reporting and distribution will continue as long as new technologies continue to pave way for such practices. This is evident from the way traditional media are losing market share with many citizens neck-deep in "participatory journalism", and other non-traditional methods of news production. This leads many to marvel at the rate at which citizens produce news peer-to-peer. With this development, nontraditional media may soon become the new public sphere (Klam, 2004).

Beyond the issue of new media replacing the old media (courtesy of non-traditional skills and tactics), the use of non-traditional skills and tactics in today's media has opened up the media landscape. Therefore, the new media, to say the least allows more people to be interested in global affairs which were not possible in the old media (Rowland, 2003). If this trend continues, the old media may have to devices survival mechanism or be ready to subsume their traditional roles to the emerging new media that is equipped with new skills and tactics to deliver news to their audiences. Additionally, media scholars argue that, the competition between the new and old media will drive the weaker underground unless the weaker acts swiftly. In line with this argument researchers are calling for a media substitution theory:

A media substitution theory that suggests that because people have a finite amount of time to devote to traditional media, when a new technology, such as the computer or the internet is introduced, people must redistribute the time they allocate to other activities and establish new patterns of behavior. (Vitalari, Venkatesh, and Gronhaug, 1985 cited in Kaye and Johnson, 2003)

\section{Pioneers of Non-traditional Media}

The use of non-traditional skills and tactics in news gathering, reporting and distribution did not start overnight. It took a gradual process. First, it was a mere migration of traditional media contents to the internet, followed by 'citizen journalism' by citizens with access to modem computers. These citizens metamorphose from news audience to news producer. Today, the media landscape is overwhelmed with such "citizen journalists" who are posing serious challenges to the traditional media. 
Tracing the history of origin of 'citizen-journalists' in today's media, one cannot but pay glowing tribute to the pioneering effort of the likes of Dan Gillmor, former print journalist turned advocate of "participatory journalism". Gillmor founded bayosphere.com, a non-profit participatory journalism website which was later bought by another participatory journalism website, backfence.com. The two sites rose to prominence amidst vibrant mainstream media market such that they were able to secure funding in recognition of their pioneering effort at democratizing news gathering, reporting and distribution (Boyles, 2007).

Backfence.com is owned by Backfence, Inc., and it serves Bethesda, Md., McLean, Va.; and Veston, Va. Bayosphere is a cooperative of local bloggers in the Bay Area of San Francisco, an area reputable for high technology (Boyles, 2006). There are other United States' "citizen journalism" media along with millions of news sites focusing on different regions around the world that successfully utilize non-traditional skills and tactics in news gathering, reporting and distribution. The Greeboro News \& Record, OhMyNews, Bakerfield, Califonia's Northwest Voice, Northwestern University's Goskokie!, University of Missouri and Washington, D.C.'s Backfence.com are very successful experiments in the use of nontraditional skills and tactics that continue to impact media landscape in the United States of America and around the world (Boyles, 2006).

\section{New Business Model}

The emergence of bloggers and other internet journalists has introduced a new business strategy to the media landscape. Unlike in the traditional media where funding of news organizations are left to owners of the organizations, 'bloggers' and other online journalists have taken to the non-traditional business model by using the internet to raise money for their news organizations. An example of individuals that used the internet to solicit financial support from readers of his blog is Andrew Sullivan, a magazine writer. He pioneers the new approach to sponsorship of online media by soliciting "money via pledges, somewhat akin to the methods of public radio and televisions" (Gillmor, 2004).

Another 'blogger', Chris Allbritton, former wire-service staff writer made history when he asked his readers to send him money to cover the war in Iraq (Gillmor, 2004). Amazingly, the readers responded to his request and he was able to go to Iraq and covered the war to the satisfaction of the readers (donors) and he continues to receive financial support from the 
readers for his media work. Joshua Micah Marshall, the author of a political blog, 'Talking Point' received $\$ 4,000$ from his readers in 2004 to cover the US presidential primaries and his coverage was one of the best that came out of the presidential primaries in New Hampshire (Gillmor, 2004).

Also, Sahara Reporter, an online news publication which reports on the sub-Sahara Africa solicits donations from the reading public to keep the web site running. According to the operator of the website, Omoyele Sowore, the publication does not accept donations from any government to preserve the publication's editorial independence and public donations are without any string attached (Aborisade, 2010).

The new business model introduced to the media landscape by 'bloggers' and other forms of online news media clearly shows that independent news producers can get paid for their creativity like the above-mentioned bloggers who were paid by their audience to cover news for them. This model clearly shows how ordinary citizen can do journalistic work for noncommercial reasons (Gillmor, 2004). This is a total departure from the practice in the traditional media where funding is by media owners and journalism is done for commercial purpose. For the new business model to be successful, the audience must be interested in the type of news the independent news producers offer them.

For this type of business model to achieve the desired result, 'citizen journalists' must be ready to do the bidding of the audience and have a good relationship with them and not just those who pay them for news coverage. The new model will go a long way to help citizen journalists and other online independent news producers stay in business. As Gillmor (2004) argues, "we are on the verge of a time when people can bring serious alternatives to the public and get paid for what they do" (p. 157). Evidently, these alternatives are the hallmark of the non-traditional skills and tactics in today's news media which helps create a new media that enhances media performance and standard.

\section{The Way Forward}

The media landscape is no doubt facing enormous challenges because of its invasion by ambitious "journalists", "bloggers", and other non-traditional skills and tactics used in news gathering, reporting and distribution. This development led the traditional media to embark 
on some changes that will enable them compete favorably with the non-traditional media. The non-traditional media as a result embarks on changes in ownership, downsizing, and more coverage of soft and sensational news (Koch, 1998). Journalists in the traditional media (newspapers, news magazines, broadcast, cable networks, and radio stations across the country) no longer hide their concerns for the threat that new media poses to old media. As Koch (1998) argues, American bookstores are inundated with books written by journalists in the traditional media "bemoaning the death of journalism as we know it" (p. 2).

With the outcry from journalists in the traditional media, non-traditional journalists who are more cyber-savvy, see non-traditional skills and tactics in media as the dawn of a new media era that will change the media landscape for better. Kalb (1998 cited in Koch 1998) notes that, "the technological revolutions of the last 20 years and the new business-oriented approach to news-gathering have transformed the ethics, values and standards of journalism" (p. 3).

Despite the avalanche of criticism against the use of non-traditional skills and tactics by news media organizations and the outcry by traditional media that the new form of journalism erodes their traditional roles, more media organizations continue to depend on non-traditional methods to boost news gathering, reporting and distribution. The mainstream media in particular, continue to urge citizens around the world to contribute news items. The implication of this is that, 'citizen-journalism', and 'news blogs' will continue as long as media organizations and society continue to see them as an alternative source of news.

With the rate at which media organizations embrace non-traditional skills and tactics to get their job done, it is evident that more and more of these skills and tactics will continue to surface from time to time. For now, the talk is about 'citizen-journalism', 'news blog', online discussion group, Facebook, Twitter etc, who knows what next. Therefore, in preparation for the future, it will be necessary to suggest that, traditional media that continue to depend on non-traditional skills and tactics find a better way to incorporate the news media into the traditional media for peaceful coexistence. This will go a long way to curtail the excesses of 'citizen-journalists' and ensure non-journalists who take to news gathering, reporting and distribution adhere to the rules of the game. 
Considering the argument for and against the use of non-traditional skills and tactics in the media, it is significant to note that, those who argue in favor of these skills and tactics are merely looking at one side of the argument. The likes of Jost and Hipolit (2002) hail 'bloggers', citizen-journalists and others who fill the 'blogsphere' with anything from personal and family photo to political advocacy and journalistic commentary underestimates the need for professionalism in media. The reality is that, there is no way non-journalists can do good journalism irrespective of how technological-savvy the individual may be.

It is arguable that, those who bemoan non-traditional skills and tactics used in the media merely see the negative effect of these skills and tactics. They ignore how they expanded news coverage, and the need for the news audience to be part of news production rather than being passive consumer of news. Media futurists argue that this trend will continue for a while. The opinion in many quarters is that, the future of media depends on how well the media is able to utilize non-traditional skills and tactics to deliver news. This brings us to the argument that peer-to-peer journalism is the journalism of the future. Perhaps the current trend is the beginning of the journey to 'peer-to-peer journalism', which is being speculated as the public sphere of the future.

What is evident from the two perspectives presented above is that, the protagonists of the use of non-traditional skills and tactics in the media are the technologically-savvy individuals who appreciate the impact of technology on media. Those who speak against the use of these skills and tactics are the non-technologically-savvy individuals who believe in the traditional media and would not want to see any reason why they should jettison the age-long traditional way of doing media work for new skills and tactics.

In view of the above analysis of non-traditional skills and tactics used in the media organizations, there is no doubt that, the use of non-traditional skills and tactics in the media has set in motion, very crucial debate on the dilemma facing today's media in the age of new technologies. The onus is therefore on the stakeholders in the media to ensure technology enhances media work and does not erode the traditional roles of the media or diminish its standards. Contemporary literature on media is silent on how the traditional media can take advantage of non-traditional skills and tactics to enhance media work; rather, it continues to 
illuminate how these skills and tactics erode the traditional roles of those involved in media work and how they constitute a threat to the traditional media.

It is an incontrovertible fact that the media will continue to use non-traditional tactics and skills as long as the tactics and skills enhance their work, irrespective of whether they erode the existing tradition or not. As expected, these skills and tactics will continue to transform news gathering, reporting, and distribution. However, any excesses that these skills and tactics bring to the media can be addressed within the confines of the media to maintain high journalistic standard and tradition. This is a challenge for future research on media if the media must meet the challenges of their traditional role as watchdog of society.

\section{Conclusion}

There is no doubt that non-traditional skills and tactics greatly impacts the way we make and consume news (Gillmor, 2004). Irrespective of how these skills and tactics change the cause of the media, what is evident is that, the media is merely responding to necessary change to ensure the profession takes advantage of the new media age that comes with the age technology. Like other professions around the world, the media is experiencing a technological revolution by utilizing technologically induced skills and tactics in their work.

As Gllimor (2004) argues, the traditional media organizations either fall in line with citizens around the world in the use of these non-traditional skills and tactic of news gathering, reporting, and distribution or become irrelevant. That is a strong wakeup call which the traditional media organizations have yet to answer. The reality for now is that the news media inundated with non-traditional skills and tactics like 'citizen-journalism', 'news blogs', internet chat groups, e-mail and a host of other skills and tactics has come to stay. These tactics and skills will continue to shape the media as long as media organizations continue to engage ordinary citizens in news production rather than allowing them to remain passive consumers of news. 


\section{References}

Aborisade, P. O. (2010). How technology transforms journalism business through citizenreporters in Nigeria. A dissertation submitted to the School of Business and Technology at Capella University in partial fulfillment of the requirements for the degree of $\mathrm{PhD}$ in Information Technology.

Barry, M. L., Vinton, G. C., David, D. C., Robert, E. K., Leonard, K., Daniel, C., Jon, P., Larry, G. R., \& Stephen, W. (2003). A brief history of the internet. Internet Society. Retrieved April 11, 2011 from http://isoc.org/internet/history/brief.shtml

Boogers, M. \& Voerman, V. (2003). Suffing citizen and floating voters: Results of an online survey of visitors to political websites during the Dutch 2002 general elections. Information Polity 8(1).

Bowman, S, and Willis, C. (2003). We media: How audiences are shaping the future of news and information. Hypergene. Retrieved December 2, 2010 from http://www.hypergenenet/wemedia

Boyles (2006).Grassroots journalism in your backyard: How citizen reporters build hyperlocal communities. A dissertation submitted to the Reed School of Journalism at West Virginia University in partial fulfillment of the requirements for the degree of $\mathrm{PhD}$ in Journalism.

Brookover, S. (2007, November). Why we blog. Library, 132 (19), 28. Retrieved December 2, 2010, from ABI/INFORM Global database.

Duarte \& Snyder (2006). Mastering virtual teams: Strategies, tools, and techniques that succeed. Jossey-Bass.

Gillmor, D. (2004). We the media: Grassroots journalism by the people, for the people. O’Reilly Media, Inc., Sebastopol, CA.

Glen, (2003). Leading Geeks: How to manage and lead people who deliver technology. Jossey-Bass.

Huysman, M., \& de Wit, D. (2002). Knowledge sharing in practice. Dordrecht: Kluwer. Jost, K., \& Hipolit, M.J. (2006). Blog explosion. CQ Researcher, 16, 505-528. Retrieved October 28, 2011, from CQ Researcher Online.

Kaye, B. K. \& Johnson, T. H. (2003). From here to obscurity?: Media substitution theory and traditional media in an on-line world. Journal of the American Society for Information Science and Technology 53(3), ABI/INFORM Global. 
Klam, M. (2004, September, 26). Fear of laptop on the campaign trail. The New York Times Magazine (p. 45).

Koch, K. (1998). Journalism under fire. CQ Researcher 8, 47. Retrieved on October 28, 2011 from CQ Researcher Online. http://library.cqpress.com.library.capella.edu

Lin, A. (2004, April 16-17).Wikipedia as participatory journalism: Reliable sources? Metric for evaluating collaborative media as a news resource. University of Texas. $5^{\text {th }}$ International Symposium on Online Journalism (p. 3).

Marshall, J. (2005, October /November). Citizen journalism continues to surge. The Quill. 93 (8) 14

Nemiro, J. E. (2004). Creativity in virtual teams: Key components for success. John Wiley \& Sons, Inc.

Occupy Nigeria activists set up "Tahrir Square" In Kano City. Sahara Reporters, (2012, January 4). Retrieved on January 4, 2012 from http://saharareporters.com/newspage/occupy-nigeria-activists-set-tahrir-square-kano-city

Permuter, D., \& McDaniel, M. (2005). The ascent of blogging. Nieman Report, 59, 60.

Pisani, T. (2005) Transforming the gathering, editing and distribution of news. Nieman Report, 59, 53.

Rick, S. (2011, December 26 2011-January 2, 2012). 2011 person of the year. Time, 178, 53. Retrieved on January 6, 2012 from http://www.time.com/time/specials/packages/article/0,28804,2101745_2102139_2102 380,00.html

Rowland, D. (2003). Whose news? Copyright and the Dissemination of News on the Internet. International Review of Law Computers and Technology, 17(2).

Senge, P. (1990). The Fifth Discipline: The art of learning and practice of the learning organization. Currency Doubleday Books.

Ward, J., \& Peppard, J. (2006). Strategic Planning for Information Systems. John Willey \& Sons, Ltd.

Widen-Wulff (2007). Utilization of information resources for business success: The knowledge sharing model. Information Resources Management Journal, 20(1). 